\title{
Mewujudkan Motivasi Kemandirian Belajar Selama Penerapan Sistem Pembelajaran Online Era Covid-19
}

\author{
Lina Khoirun Nisa \\ Universitas Sebelas Maret, Surakarta, Indonesia \\ *Corresponding author: linakhoirunnisa88@student.uns.ac.id
}

\begin{abstract}
COVID-19 has resulted in the transformation of the implementation of teaching and learning activities (KBM) from face-to-face to online. There are many basic problems during the application of online learning, one of which is the decline in student motivation while studying at home. Efforts that can be made to overcome this are independent learning. It cannot be denied that online learning does require students to create independent learning in themselves. However, the low motivation of students fosters independent learning, that is the problem. A solution is needed to help students instill learning independence in themselves, so that the online learning process can be carried out effectively like offline learning. The research method used for writing this article uses literature studies with a focus on how to foster independent learning in students as a support for learning activities at home. The results of this study are expected to be able to increase student motivation and provide an overview of fostering learning independence in students during the implementation of online learning in the COVID-19 era.
\end{abstract}

Keywords: covı-19; home learning; independent learnin; learning motivation; online learning

\begin{abstract}
ABSTRAK
COVID-19 mengakibatkan petransformasian pelaksanaan kegiatan belajar mengajar (KBM) yang semula secara tatap muka menjadi online. Banyak problematika dasar selama penerapan pembelajaran online, salah satunya adalah menurunnya motivasi siswa selama belajar di rumah. Upaya yang dapat dilakukan untuk mengatasi hal tersebut adalah dengan kemandirian belajar. Tak dapat dipungkiri bahwasanya pembelajaran online memang menuntut siswa untuk mewujudkan kemandirian belajar pada dirinya. Namun rendahnya motivasi siswa menumbuhkan kemandirian belajar, itulah yang menjadi persoalan. Perlu suatu solusi untuk membantu siswa menanamkan kemandirian belajar pada dirinya, sehingga proses pembelajaran online dapat secara efektif terlaksana layaknya pembelajaran offline. Metode penelitian yang digunakan untuk penulisan artikel ini menggunakan studi literatur dengan fokus kajian bagaimana menumbuhkan sifat kemandirian belajar dalam diri siswa sebagai penunjang aktivitas belajar selama di rumah. Hasil penelitian ini diharapkan mampu meningkatkan motivasi siswa serta memberikan gambaran untuk menumbuhkan kemandirian belajar dalam diri siswa selama pelaksanaan pembelajaran online era COVID-19.
\end{abstract}

Kata Kunci: belajar di rumah; covid-19; kemandirian belajar; pembelajaran online

\section{Pendahuluan}

Pengawalan tahun 2020, dunia mulai digemparkan dengan hadirnya wabah coronavirus (SARS-CoV atau SARSr-CoV)--COVID-19. COVID-19 pertama kali muncul di Negara China tepatnya di Kota Wuhan pada akhir tahun 2019. Kemudian wabah ini menyerang hampir ke seluruh Negara di dunia tak terkecuali Indonesia karena penyebarannya yang begitu masif. Penularan virus COVID-19 dari manusia ke manusia lain juga terbilang cepat. Menanggapi hal tersebut, pemerintah membentuk kebijakan baru untuk menekan peningkatan penyebaran COVID-19, seperti aturan wajib mematuhi protokol kesehatan, penerapan Pembatasan Sosial Berskala Besar (PSBB), lockdown, social distancing, 
dsb. Negara Indonesia mulai mengonfimasi kehadiran virus ini per tanggal 2 Maret 2020, ketika COVID-19 berhasil menginfeksi 2 warga di kota Depok. Lebih lanjut pada 11 Maret 2020 Organisasi Kesehatan Dunia (WHO) secara resmi menyatakan COVID-19 sebagai sebuah pandemi. Karena dalam waktu kurang dari tiga bulan, Covid-19 berhasil menginfeksi lebih dari 126.000 orang di 123 negara, dari benua Asia, Eropa, AS, hingga Afrika Selatan.

Berdasarkan data yang dikutip melalui laman website https://covid19.who.int/ bahwa negara Indonesia terus mengalami peningkatan kasus yang terkonfirmasi terkena COVID-19. Data statistik berikut di akses tanggal 12 April 2021.

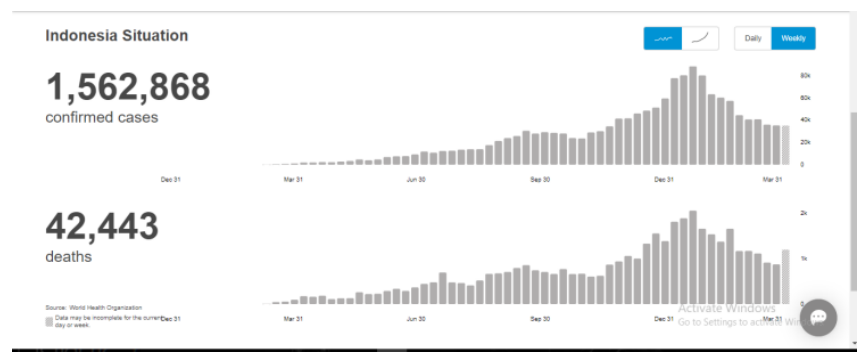

Gambar 1. Statistik peningkatan kasus COVID-19 di Indonesia

Lebih lanjut COVID-19 juga telah menjangkit sebanyak 34 provinsi yang ada di Indonesia dan terus mengalami peningkatan per harinya. Seperti yang terlihat pada gambar berikut yang dapat diakses melalui laman https://covid19.go.id/. Data berikut ini di akses tanggal 12 April 2021.

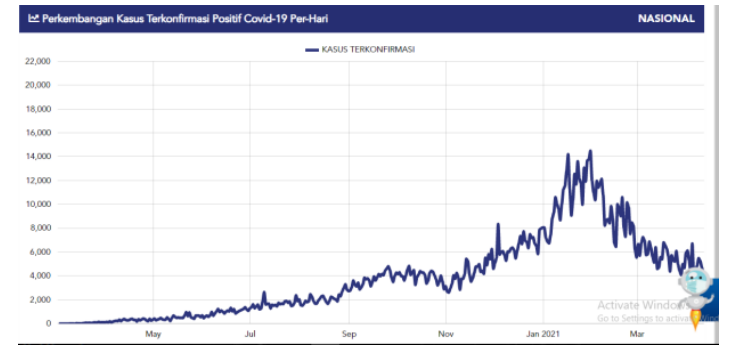

Gambar 2. Data Perkembangan Kasus Terkonfirmasi COVID-19 di Indonesia per hari

Meluasnya penyebaran COVID-19 juga berdampak signifikan pada keseluruhan aspek kehidupan tak terkecuali pendidikan. Mendikbud kemudian mengeluarkan Surat Edaran No. 4 Tahun 2020 mengenai Pelaksanaan Kebijakan Pendidikan dalam Masa Darurat Penyebaran COVID-19. Menanggapi surat edaran tersebut, banyak sekolah-sekolah memutuskan untuk melakukan pembelajaran dari rumah. Semua jenjang pendidikan, mulai dari pendidikan anak usia dini (PAUD), sekolah dasar (SD), sekolah menengah pertama (SMP), sekolah menengah atas/kejuruan (SMA/SMK), dan perguruan tinggi (PT) menerapkan kebijakan pembelajaran online. Pembelajaran online juga diakibatkan oleh pemberlakuan work from home (WFH) untuk mengantisipasi warga terinfeksi COVID-19 (Khasanah, Lestari, Rahman, \& Daniel, 2020). Bersamaan dengan hal itu, pada 17 Maret 2020 Menteri Pendidikan dan Kebudayaan mengeluarkan Surat Edaran No.: 36962/MPK.A/HK/2020 tentang Pembelajaran secara Daring dan Bekerja dari Rumah dalam rangka Pencegahan Penyebaran COVID-19. Hal ini menjadikan mutlak perubahan keseluruhan sistem pembelajaran yang semula terlaksana secara offline menjadi online selama COVID-19. 
Deputi Bidang Koordinasi Peningkatan Kualitas Pendidikan dan Moderasi Beragama Kementerian Koordinator Bidang Pembangunan Manusia dan Kebudayaan (Kemenko PMK) Agus Sartono seperti yang dikutip dalam Artikel berjudul “Tantangan Pendidikan di Masa Pandemi, Semua Orang Harus Jadi Guru" melalui laman kemenkopmk.go.id, beliau menjelaskan bahwa tujuan pendidikan adalah untuk membuat cerdas generasi penerus bangsa, serta membentuk karakter bangsa yang berbudaya. Sehingga, tantangan sebesar apapun harus bisa diatasi dan menjadi tanggung jawab bersama. Artinya hadirnya COVID-19 bukanlah penghalang pelaksanaan pembelajaran walau dalam realisasi mengharuskan perubahan pada sistemnya.

Petransformasian pelaksanaan sistem pembelajaran dari offline ke online, memang baru pertama kali terlaksana. Jika menilik sisi positifnya, petransformasian ini telah memberikan gambaran atas kelangsungan dunia pendidikan di masa depan melalui bantuan teknologi. Seperti yang dikutip dari Direktur Jenderal Pendidikan Tinggi Kemendikbud, Nizam, pada acara Medan International Conference on Energy and Sustainability, Selasa (27/10), beliau menyatakan bahwa pelaksanaan kegiatan belajar mengajar di masa pandemi menjadi tantangan tersendiri dari segi pengembangan kreativitas dengan memanfaatkan teknologi, sebagai petransmisi pengetahuan, serta memastikan pembelajaran tetap tersampaikan dengan baik. Tantangan ini juga menjadi kesempatan bagi semua terkait penggunaan teknologi untuk menyongsong digitalisasi pendidikan abad 21. Lebih lanjut keterampilan yang wajib dikuasai ialah pembelajar berjiwa mandiri sebagai outcome dari edukasi. Nizam juga menambahkan bahwa selama petransformasian pelaksanaan pembelajaran masa pandemi dapat melatih serta menanamkan kebiasaan menjadi pembelajar mandiri siswa.

Sejalan dengan pernyataan Nizam, bahwa pembelajaran online memang menuntut siswa untuk menjadi pembelajar mandiri. Meskipun demikian, demi terwujudnya hal tersebut siswa sendirilah yang harus menumbuhkan kemandirian belajar selama di rumah. Namun problematika dasar selama pelaksanaan pembelajaran online adalah masih rendahnya motivasi siswa untuk menumbuhkan kemandirian belajar dalam dirinya. Banyak siswa kehilangan semangat belajar, menurunnya motivasi belajar merasa jenuh, bahkan menyambi saat proses KBM berlangsung dengan aktivitas lain yang tak ada kaitannya dengan pembelajaran. Dengan demikian, kemandirian dalam belajar merupakan hal yang esensial untuk ditumbuhkan demi mewujudkan tercapaianya tujuan pembelajaran selama pelaksanaan pembelajaran online era COVID-19.

Berdasarkan uraian tersebut, penulis mencoba mereview dari berbagai artikel dengan tujuan penelitian untuk memberikan tinjauan umum mengenai bagaimana cara mewujudkan kemandirian belajar selama pelaksanaan pembelajaran online era COVID-19. Hal ini penting guna mengetahui bagaimana langkah yang tepat bagi siswa untuk beradapatasi menumbuhkan motivasi kemandirian belajar dalam dirinya terhadap perubahan sistem pembelajaran yang tengah diterapkan selama COVID-19 yang tidak tahu kapan akan berakhir.

\section{Metode Penelitian}


Metode penelitian yang digunakan untuk penulisan artikel ini adalah studi literatur/kajian pustaka. Studi literatur/kajian pustaka ialah studi penelitian yang dilakukan dengan menggunakan bahan karya tulis atau bahan pustaka (literatur) yang berasal dari hasil penelitian sebelumnya. (Suliyanto, 2018). Fokus kajian penelitian ini yakni bagaimana menumbuhkan sifat kemandirian belajar dalam diri siswa sebagai penunjang aktivitas belajar di rumah era COVID-19.

Selanjutnya data yang diperoleh dianalisis menggunakan teknik analisis data secara kualitatif. Analisis data kualitatif menurut pendapat Suliyanto (2018:2) menyatakan bahwa analisis kualitatif didasarkan pada data kualitatif, data yang tidak berbentuk angka atau bilangan. Yangmana data hanya berbentuk pernyataan atau kalimat. Data yang diperoleh dipilah, sesuai tema yang sesuai dengan fokus penulisan penelitian ini. Referensi ilmiah yang penulis gunakan berupa data sekunder yang diperoleh melalui jurnal internasional, nasional, portal berita serta situs website yang dapat dipertanggungjawabkan kredibilitasnya.

\section{Hasil dan Pembahasan}

\section{Pelaksanaan Pembelajaran Online Selama Pandemi COVID-19}

Pembelajaran online ialah pembelajaran yang dilaksanakan secara online melalui jaringan atau koneksi internet. Pemberlakuan pembelajaran online dinilai efektif untuk membantu memaksimalkan proses KBM tetap terlaksana walau di tengah pandemi COVID19 yang semakin mengganas. Lebih lanjut pembelajaran online mengakibatkan siswa belajar secara mandiri di rumah serta menuntut siswa untuk memiliki sikap kemandirian belajar pada dirinya.

Dalam pelaksanaan pembelajaran online guru dituntut mampu mengoperasikan teknologi untuk menyampaikan materi pembelajaran. Banyak guru yang sudah menerapkan beragam variasi dengan memanfaatkan aplikasi digital yang sudah tersedia. Aplikasi digital yang bisa digunakan seperti, Whatsapp, Google meet, Zoom, Google classroom, Web blog, Edmodo, Schoology, Quizziz dan lain-lain. Pemerintah juga ikut terlibat dalam menangani ketimpangan kegiatan belajar selama COVID-19. Terdapat 12 platform atau aplikasi yang telah pemerintah siapkan untuk mendukung proses pembelajaran di rumah, seperti Rumah belajar, Meja kita, Icando, Indonesiax, Google for education, Kelas pintar, Microsoft office 365, Quipper school, Ruang guru, Sekolahmu, Zenius, dan Cisco webex. Selama pelaksanaannya, guru juga menerapkan kegiatan pembelajaran, sehingga siswa tidak bosan selama belajar di rumah. Variatif kegiatan pembelajaran yang telah dilakukan guru misalnya saja ujian dilakukan melalui aplikasi seperti Quizziz, Edmodo, materi pembelajaran dikemas secara digital, pembelajaran dengan bermain game.

Penerapan pembelajaran online memang tidak bisa dijadikan jaminan bahwa proses pembelajaran akan tetap tersampaikan layaknya tatap muka. Beragam problematika hadir selama proses penerapannya. Selama pelaksanaannya pun banyak menuai pro kontra. Misalnya guru yang gagap teknologi, sehingga tidak mampu mengemas proses pembelajaran secara kreatif. Atau guru yang hanya dapat mengoperasikan whatsapp, sehingga guru tersebut terkadang hanya memberikan penugasan tanpa penjelasan materi. 
Pembelajaran online juga berakibat pada kurang intensifnya pemantauan pendidik kepada siswa selama proses KBM berlangsung. Yangmana pemantauan yang pendidik lakukan tak bisa seintensif layaknya pembelajaran tatap muka, terkhusus ketika siswa menonaktifkan mode kamera. Hal ini tentunya pendidik tidak mengetahui apakah siswa tersebut tetap serius mengikuti proses pembelajaran atau di "sambi" dengan aktivitas yang tidak berkaitan dengan pembelajaran.

\section{Meningkatkan Motivasi Siswa Selama Belajar di Rumah}

Proses ketercapaian tujuan pembelajaran yang telah ditetapkan, motivasi dalam diri siswa memiliki keududukan penting untuk perealisasiannya. Adanya motivasi, siswa akan lebih bersemangat dalam belajar. Maka dari itu, motivasi baik intrinsik maupun ekstrinsik harus ada pada diri siswa sehingga tujuan pembelajaran yang sudah dirumuskan dapat tercapai secara optimal.

Seperti yang telah penulis singgung sebelumnya, banyak siswa yang mengeluh mengalami penurunan motivasi belajar selama di rumah. Hal demikian juga akan berdampak pada kemandirian belajar siswa selama di rumah. Meskipun pembelajaran online menuntut setiap siswa memiliki kemandirian dalam belajar, namun bilamana tak disertai dengan motivasi belajar dalam diri siswa, se-kreatif apapun pendidik mengemas suatu metode pembelajaran daring, maka tidak akan membuahkan hasil. Hal ini juga menjadi penanda ketidaktercapaian tujuan pembelajaran selama pelaksanaan pembelajaran online. Penurunan motivasi belajar siswa selama pembelajaran online, terlihat dari banyaknya siswa yang melakukan aktivitas yang tidak berkaitan dengan pembelajaran yang ia lakukan saat proses KBM sedang berlangsung. Oleh karena itu, perlu suatu upaya untuk membangkitkan kembali motivasi dalam diri siswa, yangmana motivasi ini nantinya akan menumbuhkan kemandirian siswa selama belajar di rumah.

Upaya yang dapat dilakukan untuk menumbuhkan motivasi belajar adalah:

1. Tanam motivasi yang kuat dalam belajar. Hal ini untuk memberikan stimulus bahwa belajar bukanlah sebuah beban. Menghadirkan kecintaan akan belajar di tengah proses adaptasi dengan petransformasian sistem pembelajaran dari offline menjadi online. Banyak siswa kehilangan semangat belajar selama pelaksanaan belajar di rumah era COVID-19. Maka dari itu, untuk membangkitkan semangat belajar tetap ada, maka setiap siswa harus memiliki motivasi kuat dalam belajar.

2. Menata tempat belajar yang aman dan nyaman. Jika motivasi dalam diri telah kuat, maka siswa harus menjaga mood belajar agar tetap membaik. Salah satu caranya adalah dengan menjaga kebersihan dan kerapihan tempat belajar, akan membantu siswa lebih fokus saat pelaksanaan KBM sedang berlangsung. Suasana yang nyaman mencakup kerapihan dan kebersihan tempat belajar, akan menambah semangat belajar dan menjaga kestabilan mood belajar. Menjaga mood belajar, juga menjaga agar motivasi belajar dalam diri siswa tetap ada. Karena rusaknya mood belajar, siswa akan menjadi malas untuk melanjutkan belajar.

3. Membuat jadwal belajar harian. Hal ini selain membuat hidup akan tertata, siswa juga mudah dalam mengalokasikan lama waktu mereka belajar sehingga meminimalisir 
kejenuhan selama belajar di rumah. Membuat jadwal kegiatan harian, siswa akan mengetahui apakah kegiatannya terasa monoton atau tidak. Apabila dirasa terlalu monoton, siswa bisa menyelipkan kapan waktu untuk hiburan tanpa mengganggu aktivitas belajar wajibnya. Adanya jadwal tertata seperti ini, akan membuat siswa lebih fokus, dan terjadwal serta siswa akan berinovasi di sela-sela kegiatan hariannya. Dengan demikian, siswa tidak akan menemukan aktifitas yang menjenuhkan atau monoton.

4. Seringlah bertanya. Rusaknya mood juga disebabkan karena siswa yang kesulitan selama menyerap materi atau kesukaran mengerjakan tugas yang diberikan. Ketika kesulitan itu tidak bisa dipecahkan, akan memicu siswa menjadi malas untuk kembali belajar. Bahkan tak sedikit pula yang merasa stress akibat tugas yang susah dikerjakan. Hal ini akan sangat berdampak pada kesehatan mental siswa. Untuk itu, siswa diminta aktif bertanya. Banyak bertanya juga menandakan siswa mencoba mengeksplor materi pelajaran dan akan menumbuhkan ketertarikan pada pembelajaran. Siswa juga dapat memecahkan kesulitannya dengan berinovasi mencari media yang dapat dengan nyaman ia gunakan untuk belajar. Hal demikian akan membantu proses belajar siswa dirumah tetap berjalan dengan baik.

5. Menjaga kesehatan selama belajar di rumah. Runtutan tugas yang semakin hari semakin banyak, terkadang membuat siswa harus belajar ekstra dengan melebihi waktu atau jadwal yang telah dibuatnya. Demi mengejar dateline terkadang siswa juga mengabaikan waktu istirahatnya. Padahal siswa juga harus tetap menjaga kesehatan selama belajar di rumah. Namun bilamana siswa memang tidak memiliki waktu untuk sekedar berolahraga ringan, siswa bisa melakukan olahraga lain seperti mengatur pola duduk yang benar, melakukan senam peragangan sederhana disela-sela belajar. Lebih lanjut, siswa juga harus memperhatikan apa yang ia konsumsi baik minuman atau makanan.

\section{Mewujudkan Kemandirian Belajar dalam Diri Siswa}

Pada pemaparan sebelumnya penulis telah menguraikan bagaimana upaya untuk meningkatkan motivasi dalam belajar. Yangmana ketika siswa telah mampu menumbuhkan motivasi belajar dalam dirinya, nantinya akan berakibat pada tumbuhnya kemandirian belajar pada siswa. Hal ini sejalan dengan pendapat Mujiman (2007 : 1), beliau mengatakan bahwasanya belajar mandiri menuntut kegiatan belajar aktif, yang didorong oleh motivasi mengenai suatu kompetensi yang dimiliki. Dengan demikian kemandirian belajar siswa sangat dipengaruhi oleh bagaimana ia mampu menumbuhkan motivasi dalam belajar.

Mengacu pada pendapat tokoh tersebut, bahwasanya salah satu cara efektif untuk mewujudkan kemandirian belajar adalah dengan memanajemen diri selama pelaksanaan pembelajaran online. Kemandirian belajar hakikatnya dapat dibiasakan dengan menerapkan perilaku disiplin dalam diri siswa sehingga mampu serta terbiasa belajar mandiri melalui tindakan yang menunjang proses belajarnya-Terlepas dari bagaimanapun sistem pembelajarannya. Kemandirian belajar akan memudahkan siswa sendiri dalam menentukan cara belajar efektif sesuai dengan pribadi masing-masing, sehingga hasil belajar yang diraih pun menjadi maksimal. Selain itu siswa mampu memiliki kesadaran diri dalam belajar dan 
menjadi lebih pro aktif dalam mengikuti pembelajaran, sehingga informasi yang diberikan oleh pendidik dapat diterima dengan baik. Kemandirian dalam belajar menjadikan siswa lebih bertanggungjawab atas dirinya sendiri dalam belajar serta menginisiasi manajemen diri karena tidak memerlukan paksaan atau dorongan motivasi belajar dari orang lain. Meskipun tidak dapat dipungkiri bahwa tingkat kemampuan siswa dalam manajemen diri pastinya berbeda-beda. Namun tidak akan menjadi masalah apabila siswa memiliki kemampuan dalam kemandirian belajar. Dengan kata lain, tingkat kemandirian belajar akan berpengaruh terhadap kesiapan belajar siswa.

\section{Kesimpulan}

Keberhasilan merealisasikan mandiri belajar selama melaksanakan pembelajaran online, tentulah siswa diharapkan mampu memanajemen diri mengimplementasikan kemandirian dalam belajar selama di rumah. Mandiri belajar diharapkan siswa mampu mewujudkan karakter bertanggung jawab, kreatif, serta memiliki inisiatif yang tinggi selama belajar di rumah. Namun untuk menumbuhkan mandiri belajar, siswa harus menumbuhkan motivasi semangatnya dalam belajar. Upaya yang dapat dilakukan untuk menumbuhkan motivasi dalam belajar ialah 1) Tanam motivasi yang kuat dalam belajar; 2) Menata tempat belajar yang aman dan nyaman untuk menjaga mood selama belajar; 3) Membuat jadwal belajar dan kegiatan harian; 4) Seringlah bertanya dan terus eksplor apa yang tidak dimengerti; 5) Jangan lupa untuk selalu menjaga kesehatan. Lebih lanjut menumbuhkan mandiri belajar pada diri, siswa akan lebih mudah beradaptasi selama petransformasian sistem pembelajaran dari offline menjadi online. Dengan kemandirian belajar, siswa mampu menjadikan dirinya lebih bertanggungjawab atas dirinya sendiri dalam belajar serta menginisiasi manajemen dirinya untuk tetap termotivasi mengikuti proses pembelajaran online selama COVID-19.

\section{Daftar Pustaka}

Cahyani, A., Diah Listiana, I., \& Puteri Deta Larasati, S. (2020). Motivasi Belajar Siswa SMA pada Pembelajaran Daring di Masa Pandemi Covid-19. Jurnal Pendidikan Islam, Vol. 3, No. 1, 123-140.

Dian Pratiwi, I., \& Laksmiwati, H. (2016). Kepercayaan Diri dan Kemandirian Belajar Pada Siswa SMA Negeri “X”. Jurnal Psikologi Teori dan Terapan, Vol. 7, No. 1, 43-49.

Dwi Hastuti, W. (2020). BAB XXII MEMBANGUN MOTIVASI DAN KEMANDIRIAN PESERTA DIDIK BERKEBUTUHAN KHUSUS MELALUI FLIPPED CLASSROOM DI MASA NEW NORMAL COVID-19. Prosiding Webinar Magister Pendidikan Nonformal UNG, (hal. 181-192). Gorontalo.

Emda, A. (2017). KEDUDUKAN MOTIVASI BELAJAR SISWA DALAM PEMBELAJARAN. Lantanida Journal, Vol. 5, No. 2, 93-196.

Firman. (2020, Juni). Dampak Covid-19 terhadap Pembelajaran di Perguruan Tinggi. BIOMA, Vol. 2, No. 1, 14-20.

Fironika Kusumadewi, R., Yustiana, S., \& Nasihah, K. (2020). MENUMBUHKAN KEMANDIRIAN SISWA SELAMA PEMBELAJARAN DARING SEBAGAI DAMPAK COVID-19 DI SD. Jurnal Riset Pendidikan Dasar (JRPD), 7-13. 
Handayani, S., Annisya, \& Prasetyo Wati, A. (2020). Peningkatan Kemandirian Belajar Mahasiswa di Masa Pandemi Covid-19 melalui Penerapan Blended learning pada Mata Kuliah Evaluasi Proses dan Hasil Belajar di Universitas Negeri Malang. Jurnal Pendidikan Ekonomi, Vol. 13, No. 2, 152-164.

Hendayana, Y. (2020, Oktober 28). Tantangan Dunia Pendidikan di Masa Pandemi. Dipetik Januari 2021, 2021, dari dikti.kemdikbud.go.id: https://dikti.kemdikbud.go.id/kabardikti/kabar/tantangan-dunia-pendidikan-di-masa-pandemi/

Ika Handarini, O., \& Sri Wulandari, S. (2020). Pembelajaran Daring Sebagai Upaya Study From Home (SFH) Selama Pandemi Covid 19. Jurnal Pendidikan Administrasi Perkantoran (JPAP), Vol. 8, No. 3, 496-503.

Indrawati, B. (2020, Juli). Tantangan Dan Peluang Pendidikan Tinggi Dalam Masa Dan Pasca Pandemi Covid-19. Jurnal Kajian Ilmiah (JKI), No. 1, 39-48.

Isnawati, N., \& Samian. (t.thn.). KEMANDIRIAN BELAJAR DITINJAU DARI KREATIVITAS BELAJAR DAN MOTIVASI BELAJAR MAHASISWA. 128-144.

Marbun, \& Purim. (2020). DISAIN PEMBELAJARAN ONLINE PADA ERA DAN PASCA COVID-19. CSRID Journal, 129-142.

Pujiasih, \& Erna. (2020). MEMBANGUN GENERASI EMAS DENGAN VARIASI PEMBELAJARAN ONLINE DI MASA PANDEMI COVID-19. Jurnal Karya Ilmiah Guru, Vol. 5, No. 1, 42-48.

Sadikin, A., \& Hamidah, A. (2020). Pembelajaran Daring di Tengah Wabah Covid-19. BIODIK: Jurnal Ilmiah Pendidikan Biologi, Vol. 6, No. 2, 214-224.

Satiyasih Rosali, E. (2020, Juni). AKTIFITAS PEMBELAJARAN DARING PADA MASA PANDEMI COVID-19 DI JURUSAN PENDIDIKAN GEOGRAFI UNIVERSITAS SILIWANGI TASIKMALAYA. Geography Science Education Journal (GEOSEE), Vol. 1, No. 1, 21-30.

Setyvani Putri, G. (2020, Desember 3). WHO Resmi Sebut Virus Corona Covid-19 sebagai Pandemi Global. Dipetik Desember 29, 2020, dari kompas.com: https:/ / www.kompas.com/sains/read/2020/03/12/083129823/who-resmi-sebutvirus-corona-covid-19-sebagai-pandemi-global?page=all.

Sudarsana, K., \& dkk. (2020). COVID-19 Prespektif Pendidikan. Medan: Yayasan Kita Menulis.

Suprihatin, S. (2015). UPAYA GURU DALAM MENINGKATKAN MOTIVASI BELAJAR SISWA. JURNAL PROMOSI: Jurnal Pendidikan Ekonomi UM Metro, Vol. 3, No. 1, 73-82.

Tantangan Pendidikan di Masa Pandemi, Semua Orang Harus Jadi Guru. (2020, Desember 11). Dipetik Januari 16, 2021, dari kemenkopmk.go.id: https://www.kemenkopmk.go.id/tantangan-pendidikan-di-masa-pandemi-semuaorang-harus-jadi-guru

Tips Belajar Sehat Dirumah Selama Pandemi Covid 19. (2020, Mei 29). Dipetik Januari 22, 2021, dari stikesbanyuwangi.ac.id: https://stikesbanyuwangi.ac.id/tips-belajar-sehat-dirumahselama-pandemi-covid-19/

Yuyu, Y., \& Dudu, S. S. (2020). MEMBANGUN KEMANDIRIAN BELAJAR MAHASISWA MELALUI BLENDED LEARNING DI MASA PANDEMI COVID-19. Jurnal Elementaria Edukasia, Vol. 3, No. 1, 142-149. 